\title{
Behavioral effects of aqueous and dichloromethane extracts of Erythrina speciosa Andrews, Fabaceae, leaves in mice
}

\author{
Gabriela Lollato, ${ }^{1}$ Ieda S. Scarminio, ${ }^{2}$ Estefania G. Moreira ${ }^{* 1}$
}

\begin{abstract}
${ }^{l}$ Departmento de Ciências Fisiológicas, Centro de Ciências Biológicas, Universidade Estadual de Londrina, Campus Universitário, 86055-900 Londrina-PR, Brazil,

${ }^{2}$ Departmento de Química, Universidade Estadual de Londrina, Campus Universitário, 86055-900 Londrina-PR, Brazil.
\end{abstract}

\begin{abstract}
RESUMO: "Efeitos comportamentais do extrato aquoso bruto e fração diclorometano das folhas de Erythrina speciosa Andrews, Fabaceae, em camundongos". Erythrina speciosa Andrews, Fabaceae, é usada na região Sul do Brasil como sedativa e tranquilizante. Neste estudo, uma possível ação central do extrato aquoso (EA) e fração diclorometano (DCM) das folhas da E. speciosa foi avaliada em camundongos machos submetidos a testes comportamentais $1 \mathrm{~h}$ após o tratamento (gavage). Também foi avaliada a dose letal 50\% (DL50) como indicativa da toxicidade aguda desta planta. O EA diminuiu a locomoção (50, 100 e $400 \mathrm{mg} / \mathrm{kg}$ ) e o levantar (50 e $400 \mathrm{mg} / \mathrm{kg}$ ) no teste de campo aberto mas não alterou nenhum dos comportamentos avaliados nos testes de labirinto em cruz elevado, rotarod e sono induzido. A DCM não alterou nenhum dos comportamentos avaliados. A DL50 de ambos os extratos foi estimada como sendo $>2000 \mathrm{mg} / \mathrm{kg}$. Os resultados sugerem ausência de efeito ansiolítico e depressor do Sistema Nervoso Central das folhas de E. speciosa. Entretanto, como mecanismos serotonérgicos podem estar envolvidos na ação farmacológica de plantas do gênero Erythrina e o teste de labirinto em cruz elevado não é adequado para avaliar o efeito de drogas serotonérgicas, nossos resultados não invalidam o uso desta planta na medicina popular, mas apontam a necessidade de se investigar o mecanismo de ação envolvido no possível efeito central de plantas do gênero Erythrina.
\end{abstract}

Unitermos: Erythrina speciosa, campo aberto, labirinto em cruz elevado, roratod, sono induzido, dose letal.

\begin{abstract}
Erythrina speciosa Andrews, Fabaceae, is used in the South of Brazil as sedative and tranquilizers. In this study, behavioral effects of aqueous (AE) and dichloromethane (DCM) extracts of E. speciosa leaves were evaluated in male mice, as well as their lethal dose $50 \%$ (LD50). The extracts were administered by gavage in doses ranging from 50 to $400 \mathrm{mg} / \mathrm{kg} 1 \mathrm{~h}$ before the behavioral tests. AE decreased ambulation $(50,100$ and $400 \mathrm{mg} / \mathrm{kg}$ ) and rearing (50 and $400 \mathrm{mg} / \mathrm{kg}$ ) in the open-field but did not influence elevated plus maze, rotarod and pentobarbital-induced sleep tests. No behavioral effects were observed after DCM administration. LD50 for both extracts were higher than $2000 \mathrm{mg} / \mathrm{kg}$. The results showed that AE and DCM extracts of E. speciosa leaves do not produce anxiolytic effect in the elevated plus maze nor seems to depress the Central Nervous System. However, since serotonergic mechanisms may be involved in the pharmacological action of Erythrina plants and the elevated plus maze test is not adequate to evaluate serotonergic drugs, our results do not invalidate the use of this plant in folk medicine but suggest that the mechanism involved in a possible central action of Erythrina needs to be clarified.
\end{abstract}

Keywords: Erythrina speciosa, open-field; elevated plus maze; rotarod; pentobarbital-induced sleep; lethal dose. 


\section{INTRODUCTION}

Several species of Erythrina, Fabaceae, are reported in folk medicine as tranquilizers and sedatives. In Brazil three species have been used: E. velutina, $E$. mulungu and E. speciosa (Lorenzi, 1992). Despite of its common use, there are few pharmacological studies on this genus. The curare-like effect has long been known (Lehman, 1937). Regarding central nervous system activity, sedative, anticonvulsant and anxiolytic effects have been reported with extracts from stem bark, flowers or leaves of E. mulungu or E. velutina (Onusic et al., 2002; Dantas et al., 2004; Flausino et al., 2007; Vasconcelos et al., 2007; Raupp et al., 2008).

Considering the folk use of Erythrina speciosa Andrews in the South of Brazil and the lack of pharmacological studies with this species, we investigated, in mice, possible central effects of aqueous extract from leaves. Moreover, since alkaloids have been suggested as the central active components of Erythrina (Flausino et al., 2007) and dichloromethane was suggested to be the best extractor for erythrinan alkaloids in flowers (Silva, 2003), the dichloromethane extract was also investigated. As an indicative of acute toxicity, lethal dose $50 \%$ (LD50) was estimated.

\section{MATERIALS AND METHODS}

\section{Plant material}

The plant (Erythrina speciosa Andrews, Fabaceae) was collected at the Universidade Estadual de Londrina (UEL), Paraná, Brazil on March, 2007. A voucher specimen was deposited in the herbarium of UEL (FUEL 35133) and authenticated by M.R.C. Paiva.

For the aqueous extract (AE) preparation, fresh leaves were washed and dried. Powdered leaves were extracted with distilled water $(1 \mathrm{~g} / 10 \mathrm{~mL})$ at $100{ }^{\circ} \mathrm{C}$ for $30 \mathrm{~min}$. The AE was filtered, lyophilized and stored at $-20{ }^{\circ} \mathrm{C}$. For the dichloromethane (DCM) extraction, 3 $\mathrm{g}$ of powdered leaves and $60 \mathrm{~mL}$ of solvent were used and after $24 \mathrm{~h}$ the material was filtered. The solvent was evaporated under reduced pressure and the $\mathrm{w} / \mathrm{w}$ extraction yield was $24 \%$.

\section{Animals}

Male Swiss mice (25-35 g) from the institutional colony were acclimatized for seven days in a temperatureand light- controlled room under a $12 \mathrm{~h}$ light/12 h dark cycle (lights on at 6:00 am). They had free access to tap water and food, except for a fasting period of $3 \mathrm{~h}$ before the experiments. The experimental procedures were approved by the UEL Animal Ethics Committee (protocol number CEEA 54/06). All mice were experimentally naive and were used only once.

\section{Extract administration}

AE was dissolved in distilled water and DCM in Cremophor $^{\circledR}$ (Basf) $5 \%(\mathrm{v} / \mathrm{v})$ immediately before experiments. Control groups were treated with these solvents (vehichle, VEH). Both extracts and VEH were administered orally (p.o., gavage) $1 \mathrm{~h}$ before the behavioral evaluation and the doses were selected based on studies conducted with other species of Erythrina (Onusic et al., 2002; Flausino et al., 2007; Vasconcelos et al., 2007).

\section{Behavioral evaluation}

In order to avoid the unnecessary use of animals, a tier approach was adopted, i.e., the behavioral tests as well as the doses evaluated in each test were chosen accordingly to the results obtained in previous steps. Open-field and elevated plus maze sessions were recorded by a video camera, linked to a monitor in an adjacent room and videotapes were analyzed blindly. After each evaluation, the apparatuses were cleaned with ethanol $5 \%$.

Open-field test

Mice treated with $0,50,100,200$ and $400 \mathrm{mg} /$ $\mathrm{kg}$ of $\mathrm{AE}$ or $0,50,100$ and $200 \mathrm{mg} / \mathrm{kg}$ of DCM were submitted to the open-field test as described elsewhere (Lisboa et al., 2007). Ambulation, rearing and grooming were recorded during a 3-min session.

\section{Elevated plus-maze test}

Mice treated with 0 and $200 \mathrm{mg} / \mathrm{kg}$ of AE or 0 , 50,100 and $200 \mathrm{mg} / \mathrm{kg}$ of DCM were submitted to the elevated plus maze as described elsewhere (Lisboa et al., 2007). The number of entries into, and the time spent in the open and closed arms were registered for $5 \mathrm{~min}$. The percentage of entries in the open arms was obtained dividing the number of entries in open arms by the total number of entries. The percentage of time spent in the open arms was obtained by dividing the time spent in the open arms by total time spent in both arms.

\section{Pentobarbital-induced sleep}

Mice treated with 0, 50, 100, 200 and $400 \mathrm{mg} /$ $\mathrm{kg}$ of $\mathrm{AE}$ were injected intraperitoneally (i.p.) with 50 $\mathrm{mg} / \mathrm{kg}$ of sodium pentobarbital (Cristália). The latency and duration of sleep (loss of the righting reflex) were recorded (Wambebe, 1985). The time limit for the duration of sleep was fixed at $2 \mathrm{~h}$. 


\section{Rotarod test}

Mice were trained on a rotarod (Insight) at $4 \mathrm{rpm}$ for $2 \mathrm{~min}$, three times on the day prior to the experiment. On the test day, mice that could not retain their balance on the accelerating bar (6 to $12 \mathrm{rpm}$ ) for $2 \mathrm{~min}$ were discarded. Mice were treated with 0,50 and $400 \mathrm{mg} / \mathrm{kg}$ of $\mathrm{AE}$ and after $1 \mathrm{~h}$ they were placed on the accelerating bar (6 to $16 \mathrm{rpm}$ in $3 \mathrm{~min}$ ). The times that the mice remained on the rotating rod were recorded. The time limit was fixed at $3 \mathrm{~min}$.

\section{LD50}

Oral LD50 was estimated in male mice following the guideline 423 from the Organization for Economics Cooperation and Development (OECD, 2001). The starting dose was $2000 \mathrm{mg} / \mathrm{kg}$.

\section{Statistical analysis}

Data were analyzed by ANOVA followed by Student-Newman-Keuls (SNK), except for AE in the elevated plus-maze, which data were analyzed by Student's t test. The level of significance was set at 5\%.

\section{RESULTS}

Behavioral evaluation results of $\mathrm{AE}$ are presented in Table 1. We started evaluating the general activity of animals in the open-field and observed that, compared to VEH, AE significantly decreased both ambulation (50, 100 and $400 \mathrm{mg} / \mathrm{kg})$ and rearing (50 and $400 \mathrm{mg} / \mathrm{kg}$ ) behaviors. Since the elevated plusmaze test is only valid to evaluate anxiolytic effect if motor function is not altered (Dawson et al., 1995), only the dose of $200 \mathrm{mg} / \mathrm{kg}$ of AE was tested in this model. Student's t test showed no difference between AE and VEH both in percentage of open arm entries and of time spent in the open arms. To evaluate if the decreased ambulation and rearing observed in the open-field could be due to AE-induced motor coordination disturbance, mice administered with doses that compromised both of those behaviors in the open-field (50 and $400 \mathrm{mg} / \mathrm{kg}$ ) were tested in the rotarod. No statistical difference was detected between treated and control groups. Finally, to evaluate possible central nervous system depressant action of the AE extract, pentobarbital-induced sleep was conducted with mice previously treated with $\mathrm{AE}$ but none of the doses evaluated $(0,50,100$ and $400 \mathrm{mg} /$ $\mathrm{kg}$ ) potentiated the pentobarbital effect.

As can be seen in Table 2, DCM did not induce behavioral effects either in the open-field or the elevated plus maze tests. In this way, pentobarbitalinduced sleep and rotarod test were not conducted.

Regarding the LD50 estimation, we followed a guideline from OECD that employs a validated methodology to estimate LD50 with a few number of animals. We started administering $2000 \mathrm{mg} / \mathrm{kg}$ of AE or DCM for three animals and observing them for two weeks. Since no death or sign of toxicity were observed, the same procedure was repeated with another set of three animals for each extract. Again, no death was observed and, following the guideline, the evaluation was ended and the LD50 was estimated as being higher than $2000 \mathrm{mg} / \mathrm{kg}$.

Table 1. Behavioral evaluation of the AE from Erythrina speciosa Andrews, Fabaceae, leaves.

\begin{tabular}{|c|c|c|c|c|c|}
\hline & \multirow[b]{2}{*}{ VEH } & \multicolumn{4}{|c|}{ E. speciosa (mg $/ \mathrm{kg}$, p.o.) } \\
\hline & & 50 & 100 & 200 & 400 \\
\hline \multicolumn{6}{|l|}{ Open-field } \\
\hline Ambulation (count) & $83.4 \pm 5.1(12)$ & $50.6 \pm 3.5 \#(11)$ & $64.6 \pm 4.3 *(11)$ & $71.2 \pm 4.9(12)$ & $51.8 \pm 6.0 \#(10)$ \\
\hline Rearing (count) & $22.9 \pm 2.1(12)$ & $11.3 \pm 1.4 *(11)$ & $16.6 \pm 2.3(11)$ & $20.0 \pm 2.0(12)$ & $10.5 \pm 1.1 \#(10)$ \\
\hline Grooming (s) & $4.4 \pm 0.9(12)$ & $8.1 \pm 2.1(11)$ & $5.2 \pm 0.6(11)$ & $6.2 \pm 1.5(12)$ & $5.4 \pm 1.1(10)$ \\
\hline \multicolumn{6}{|l|}{ Elevated plus maze } \\
\hline$\%$ open arm entries & $0.28 \pm 0.03(23)$ & -- & -- & $0.27 \pm 0.02(26)$ & -- \\
\hline$\%$ open arm duration & $0.18 \pm 0.02(23)$ & -- & -- & $0.24 \pm 0.03(26)$ & -- \\
\hline \multicolumn{6}{|l|}{ Pentobarbital-induced sleep } \\
\hline Latency to sleep (s) & $4.5 \pm 0.6(10)$ & $4.8 \pm 0.4(10)$ & $7.8 \pm 1.7(9)$ & $4.0 \pm 0.2(10)$ & $6.1 \pm 1.0(10)$ \\
\hline Duration of sleep (s) & $58.7 \pm 6.9(10)$ & $65.0 \pm 7.4(10)$ & $69.2 \pm 13.0(9)$ & $61.5 \pm 7.2(10)$ & $59.5 \pm 7.7(10)$ \\
\hline \multicolumn{6}{|l|}{ Rotarod } \\
\hline Time in the rotating bar $(\mathrm{s})$ & $145.0 \pm 16.8(9)$ & $149.5 \pm 13.2(11)$ & -- & -- & $150.0 \pm 17.3(11)$ \\
\hline
\end{tabular}

Data are means \pm SEM. Number in parentheses represent the number of animals evaluated. VEH: distilled water. * $p<0.05$ and $\# p<0.001$ compared to VEH (ANOVA complemented with SNK); s: seconds. 
Table 2. Behavioral evaluation of the DCM from Erythrina speciosa Andrews, Fabaceae, leaves.

\begin{tabular}{lcccc}
\hline \multicolumn{4}{c}{ E. speciosa $(\mathrm{mg} / \mathrm{kg}$, p.o. $)$} \\
\hline Open-field & VEH & 50 & 100 & 200 \\
Ambulation (count) & $73.0 \pm 6.9(10)$ & $71.7 \pm 6.1(10)$ & $69.7 \pm 6.2(10)$ & $75.7 \pm 5.6(9)$ \\
Rearing (count) & $15.9 \pm 1.6(10)$ & $19.3 \pm 1.0(10)$ & $14.4 \pm 1.3(10)$ & $14.0 \pm 2.1(10)$ \\
Grooming(s) & $5.8 \pm 1.5(10)$ & $4.4 \pm 1.4(10)$ & $3.2 \pm 1.0(10)$ & $3.6 \pm 1.0(9)$ \\
Elevated plus maze & & & & $0.19 \pm 0.02(11)$ \\
\% open arm entries & $0.20 \pm 0.03(10)$ & $0.22 \pm 0.04(11)$ & $0.16 \pm 0.02(10)$ & $0.21 \pm 0.02(9)$ \\
$\%$ open arm duration & $0.18 \pm 0.02(10)$ & $0.12 \pm 0.02(11)$ & & $0.15 \pm 0.03(10)$ \\
\hline
\end{tabular}

Data are means \pm SEM. Number in parentheses represent the number of animals evaluated. VEH: Cremophor ${ }^{\circledR} 5 \%$; s: seconds.

\section{DISCUSSION AND CONCLUSIONS}

In the present study, possible central nervous system effects of AE and DCM from E. speciosa leaves were evaluated in male mice submitted to behavioral tests. In the open-field, AE decreased both ambulation and rearing and did not alter grooming, suggesting decreased motor activity in the absence of emotionality alteration (Broadhurst, 1960). In order to determine if the decreased motor activity was due to central or peripheral action, AE was evaluated in the pentobarbital-induced sleep, which screens for central depressants, and rotarod test, which evaluates motor coordination and may be disturbed by drugs that act centrally and/or peripherally. The lack of AE effect in the rotarod test corroborates studies conducted with other Erythrina species (Vasconcelos et al., 2004) and discard the involvement of a neuromuscular blockade on the effect observed in the open-field. On the other hand, the lack of AE effect in the pentobarbital-induced sleep was surprising since potentiation of pentobarbital-induced sleep have been described for $\mathrm{AE}$ from E. velutina leaves $(10,100,300$ and $400 \mathrm{mg} / \mathrm{kg}$, i.p.) and hydroalcoholic extract from $E$. mulungu stem bark (200 mg/kg, i.p.) (Dantas et al., 2004; Vasconcelos et al., 2007).

Considering the folk use of Erythrina as an anxiolytic plant and that this effect has been described in experimental studies with different Erythrina species (Onusic et al., 2002; Dantas et al., 2004; Ribeiro et al., 2006; Flausino, 2007) in this work we investigated if $\mathrm{AE}$ and DCM of E. speciosa would induce anxiolytic effect in the elevated plus maze, the most classic test to evaluate anxiety experimentally. No alteration in the percentage of open arm entries and time spent in the open arms was observed for both AE and DCM, suggesting that this species would not be anxiolytic. Interestingly, despite the fact that Dantas et al. (2004) described anxiolytic effect for AE from E. mulungu leaves $(20 \mathrm{mg} /$ $\mathrm{kg}$, i.p.) in the elevated plus maze, other studies with $\mathrm{E}$. mulungu and E. velutina failed to demonstrate such an effect in this test (Vasconcelos et al., 2004; Flausino et al., 2007). Recently, Raupp et al. (2008) also failed to show anxiolytic effect after acute administration of the hydroalcoholic extract of the stem bark of E. velutina but they did detect an anxiolytic effect after a 23-26 days repeated administration of the $100 \mathrm{mg} / \mathrm{kg}$ dose.

Some studies have suggested that the central effects of Erythrina could be mediated by the neurotransmitter GABA (Onusic et al., 2002; Vasconcelos et al., 2007) based on the observation that the efficacy of the extracts was similar to the efficacy of benzodiazepine drugs used as positive controls or reference drugs. This suggestion could be corroborated by an in vitro study with guinea-pig ileum that showed, among other mechanisms of action, GABAA receptor activation in response to $\mathrm{AE}$ from E. velutina leaves (Carvalho et al., 2009). However, we could not find behavioral studies that investigated this proposed mechanism of action through the concomitant use of antagonists of gabaergic and/or benzodiazepine receptors. It is noteworthy to mention that the elevated plus maze test is very sensitive to detect anxiolytic effect induced by benzodiazepine-like drugs (Pinheiro et al., 2007) and the failure of this test to reveal the anxiolytic effect of Erythrina not only in the present study but also in previous ones raises a red flag on a possible gabaergicbenzodiazepine mechanism of action for the central effects of Erythrina species.

Another neurotransmitter that has been suggested to be involved in the anxiolytic effect of Erythrina is serotonin (Flausino et al., 2007). The crude extract of $E$. vespertilio inhibited platelet serotonin release, which is a model for studying calcium-dependent serotonin release (Rogers et al., 2001). In addition, the alkaloid $\beta$-erythroidine seems to be an antagonist of 5-HT3 receptors (Eiselé et al., 1993). A serotonergic action could explain many of the results that have been observed in the pharmacological screening of plants from the genus Erythrina because: i) it is classically recognized the false negative results of anxiolytic serotonergic drugs in the elevated plus maze test after acute administration (Handley \& Macblane, 1993); ii) serotonergic drugs are more likely to induce anxiolytic effect in the elevated plus 
maze after repeated treatment (Silva \& Brandão, 2000), which has been observed by Raup et al. (2008) with the hydroalcoholic extract of $E$. mulungu; iii) similarly to the results obtained in the present study, serotonergic anxiolytic drugs, like buspirone, do not potentiate the effect of hypnotics but do decrease motor activity in the open-field (Andreatini et al., 2001; Shireen \& Haleem, 2005; Vadiya et al., 2005). Despite those evidences, the serotonergic involvement on the Erythrina central action is so far just a speculation and future studies should specifically address this issue.

It was somewhat surprising the complete lack of behavioral effects of the DCM extract because DCM has been suggested as the best extractor for erythrinan alkaloids in flowers (Silva, 2003) and alkaloids have been claimed as the central active components of Erythrina (Flausino et al., 2007). One possibility, is that since alkaloids have low stability and are sensitive to light, $\mathrm{pH}$ and some organic solvents, including chloroform and DCM (Henriques et al., 2004), the extraction conducted in our study may have resulted in the loose of pharmacological activity of the alkaloids.

Regarding the acute toxicity of E. speciosa, the result obtained in this study suggests it as having low acute toxicity since the estimated LD50 was higher than $2000 \mathrm{mg} / \mathrm{kg}$. The OECD guideline discourage the testing of doses higher than $2000 \mathrm{mg} / \mathrm{kg}$ and recommends that this should only be considered when there is a strong likelihood that results of such a test have a direct relevance for protecting human or animal health (OECD, 2001). This was not the case in the present study because two other studies conducted with $E$. velutina described the oral LD50 of the AE from leaves of this species as being higher than $5000 \mathrm{mg} / \mathrm{kg}$ (Bonfim, 2001; Craveiro et al., 2008). Taken together the LD50 results suggest that species from the genus Erythrina found in Brazil may have low acute toxicity. However, it is important to recognize that having low acute toxicity does not mean that those plants lack toxicity and a complete toxicity evaluation following national and international guidelines is necessary before attesting the safety of Erythrina species as phytomedicines.

In conclusion, the results showed that the only behavioral effect induced by AE extract of E. speciosa leaves was a decreased motor activity in the open-field test. However, the lack of effect in the elevated plus maze test does not invalidate the use of this plant in folk medicine as anxiolytic since this test is not adequate to evaluate drugs with mechanisms of action differently from the gabaergic-benzodiazepine one. Future studies are necessary to clarify the mechanism of action of $E$. speciosa and validate its folk use as anxiolytics.

\section{ACKNOWLEDGEMENTS}

Araucária.
This study was supported by Fundação

\section{REFERENCES}

Andreatini R, Boerngen-Lacerda R, Zorzetto Filho D 2001. Tratamento farmacológico do transtorno de ansiedade generalizada: perspectivas futuras. Rev Bras Psiquiatr 23: 233-242.

Bonfim KBR 2001. Farmacologia de plantas medicinais analgésicas de uso popular da caatinga. Aracaju 153 p. Dissertação de Mestrado, Núcleo de Pós-graduação em Desenvolvimento e Meio Ambiente, Universidade Federal de Sergipe.

Broadhurst PL 1960. Experiments in psychogenetics. In: Eysenk, H.J. Experiments in personality. London: Rutledge and Kegan Paul, p. 31-61.

Craveiro ACS, Carvalho DMM, Nunes RS, Fakhouri R, Rodrigues AS, Teixeira-Silva F 2008. Toxicidade aguda do extrato aquoso de folhas de Erythrina velutina em animais experimentais. Rev Bras Farmacogn 18 (Supl): 739-743.

Carvalho ACCS, Almeida DS, Melo MGD, Cavalcanti SCH, Marçal RM 2009. Evidence of the mechanism of action of Erythrina velutina Willd (Fabaceae) leaves aqueous extract. J Ethnopharmacol 122: 374-378.

Dantas MC, de Oliveira FS, Bandeira SM, Batista JS, Silva Jr CD, Alves PB, Antoniolli AR, Marchioro M 2004. Central nervous system effects of the crude extract of Erythrina velutina on rodents. J Ethnopharmacol 94: 129-133.

Dawson GR, Crawford SP, Collinson N, Iversen SD, Tricklebank MD 1995. Evidence that the anxiolytic-like effects of chlordiazepoxide on the elevated plus maze are confounded by increases in locomotor activity. Psychopharmacology 118: 316-323.

Eiselé JL, Bertrand S, Galzi JL, Devillers-Thiéry A, Changeux JP, Bertrand D 1993. Chimaeric nicotinic-serotonergic receptor combines distinct ligand binding and channel specificities. Nature 366: 479-483.

Flausino OA, Pereira AM, Bolzani VS, Nunes-de-Souza RL 2007. Effects of erythrinian alkaloids isolated from Erythrina mulungu (Papilonaceae) in mice submitted to animal models of anxiety. Biol Pharm Bull 30: 375378.

Handley SL, Macblane JW 1993. 5-HT drugs in animal models of anxiety. Psychopharmacology 112: 13-20.

Henriques AM, Limberger RP, Kerber VA, Moreno PRH 2004. Alcalóides: generalidade e aspectos básicos. In Simões CMO, Schenkel EP, Gosmann G, Mello JCP, Mentz LA, Petrovick PR (orgs). Farmacognosia: da planta ao medicamento. 5. ed. Porto Alegre/Florianópolis: UFRGS, UFSC, p. 765-792.

Lehman AJ 1937. Actions of Erythrina americana, a possible curare substitute. J Pharmacol Exp Ther 60: 69.

Lisboa SFS, Oliveira PE, Costa LC, Venâncio EJ, Moreira EG 2007. Behavioral evaluation of male and female mice pups exposed to fluoxetine during pregnancy and lactation. Pharmacology 80: 49-56.

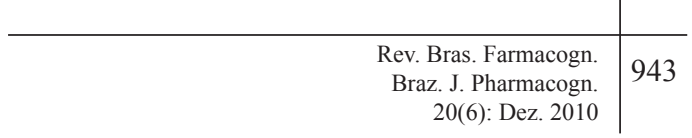


Lorenzi H 1992. Árvores brasileiras: manual de identificação e cultivo de plantas arbóreas nativas do Brasil. Nova Odessa: Plantarum.

Onusic GM, Nogueira RL, Pereira AMS, Viana MB 2002. Effect of acute treatment with a water-alcohol extract of Erythrina mulungu on anxiety-related responses in rats. Braz J Med Biol Res 35: 473-477.

Organization for Economic Co-operation and Development 2001. Guideline 423: Guideline for testing of chemicals: acute oral toxicity - acute toxic class method. Paris: OECD.

Pinheiro SH, Zangrossi Jr H, Del-Bel ECM, Graeff FG. Elevated mazes as animal models of anxiety: effects of serotonergic agents, 2007. An Acad Bras Cienc 79: 71-85.

Raupp IM, Sereniki A, Virtuoso S, Ghislandi C, Cavalcanti e Silva EL, Trebien HA, Miguel OG 2008. Anxiolyticlike effect of chronic treatment with Erythrina velutina extract in the elevated plus-maze test. JEthnopharmacol 118: 295-299.

Ribeiro MD, Onusic GM, Poltronieri SC, Viana MB 2006. Effect of Erythrina velutina and Erythrina mulungu in rats submitted to animal models of anxiety and depression. Braz J Med Biol Res 39: 263-270.

Rogers KL, Grice ID, Griffiths LR 2001. Modulation of in vitro platelet 5-HT release by species of Erythrina and Cymbopogon. Life Sci 69: 1817-1829.

Shireen E, Haleem DJ 2005. Motor effects of buspirone: relationship with dopamine and serotonin in the striatum. J Coll Physicians Surg Pak 15: 753-756.

Silva RCB, Brandão ML 2000. Acute and chronic effects of gepirone and fluoxetine in rats tested in the elevated plus-maze: an ethological analysis. Pharmacol Biochem Behav 65: 209-216.

Silva WH 2003. Planejamento experimental para extração de alcalóides das flores de Erythrina speciosa e estudo químico do extrato em acetato de etila. Londrina $54 \mathrm{p}$. Monografia de graduação em Química, Universidade Estadual de Londrina.

Vadiya AH, Rosenthal DI, Lang W, Crooke JJ, Benjamin D, Ilyin SE, Reitz AB 2005. Oral buspirone causes a shift in the dose-response curve between the elevated plus-maze and Vogel conflict tests in long-Evans rats: relation of brain levels of buspirone and 1-PP to anxiolytic action. Meth Find Exp Clin Pharmacol 27: 245-255.

Vasconcelos SMM, Lima NM, Sales GTM, Cunha GM, Aguiar LMV, Silveira ER, Rodrigues ACP, Macedo DS, Fonteles MMF, Sousa FCF, Viana GSB 2007. Anticonvulsant activity of hydroalcoholic extracts from Erythrina velutina and Erythrina mulungu. J Ethnopharmacol 110: 271-274.

Vasconcelos SMM, Macedo DS, de Melo CT, Monteiro AP, Rodrigues AC, Silveira ER, Cunha GM, Souza FC, Viana GS 2004. Central activity of hydroalcoholic extracts from Erythrina velutina and Erythrina mulungu in mice. J Pharm Pharmacol 56: 389-393.

Wambebe C 1985. Influence of some agents that affect 5-hydroxy-tryptamine metabolism and receptors on nitrazepam-induced sleep in mice. Br J Pharmacol 84: 185-191. 